\title{
Cloud droplet activation of secondary organic aerosol is mainly controlled by molecular weight, not water solubility
}

\author{
Jian Wang ${ }^{1,2}$, John E. Shilling ${ }^{3}$, Jiumeng Liu ${ }^{3, a}$, Alla Zelenyuk ${ }^{4}$, David M. Bell ${ }^{4, b}$, Markus D. Petters ${ }^{5}$, \\ Ryan Thalman ${ }^{1, c}$, Fan Mei $^{3}$, Rahul A. Zaveri ${ }^{3}$, and Guangjie Zheng ${ }^{1,2}$ \\ ${ }^{1}$ Environmental and Climate Sciences Department, Brookhaven National Laboratory, Upton, New York 11973, USA \\ ${ }^{2}$ Center for Aerosol Science and Engineering, Department of Energy, Environmental and Chemical Engineering, \\ Washington University in St. Louis, Missouri, USA \\ ${ }^{3}$ Atmospheric Sciences and Global Change Division, Pacific Northwest National Laboratory, \\ Richland, Washington 99354, USA \\ ${ }^{4}$ Physical Sciences Division, Pacific Northwest National Laboratory, Richland, Washington 99354, USA \\ ${ }^{5}$ Department of Marine, Earth, and Atmospheric Sciences, North Carolina State University at Raleigh, \\ Raleigh, North Carolina 27695, USA \\ a present address: School of Environment, Harbin Institute of Technology, Harbin, 150001, China \\ ${ }^{b}$ present address: Laboratory of Atmospheric Chemistry, Paul Scherrer Institute, 5232 Villigen-PSI, Switzerland \\ ${ }^{c}$ present address: Department of Chemistry, Snow College, Richfield, Utah 84627, USA
}

Correspondence: Jian Wang (jian@wustl.edu)

Received: 13 July 2018 - Discussion started: 24 July 2018

Revised: 21 November 2018 - Accepted: 21 November 2018 - Published: 24 January 2019

\begin{abstract}
Aerosol particles strongly influence global climate by modifying the properties of clouds. An accurate assessment of the aerosol impact on climate requires knowledge of the concentration of cloud condensation nuclei (CCN), a subset of aerosol particles that can activate and form cloud droplets in the atmosphere. Atmospheric particles typically consist of a myriad of organic species, which frequently dominate the particle composition. As a result, $\mathrm{CCN}$ concentration is often a strong function of the hygroscopicity of organics in the particles. Earlier studies showed organic hygroscopicity increases nearly linearly with oxidation level. Such an increase in hygroscopicity is conventionally attributed to higher water solubility for more oxidized organics. By systematically varying the water content of activating droplets, we show that for the majority of secondary organic aerosols (SOAs), essentially all organics are dissolved at the point of droplet activation. Therefore, for droplet activation, the organic hygroscopicity is not limited by solubility but is dictated mainly by the molecular weight of organic species. Instead of increased water solubility as previously thought, the increase in the organic hygroscopicity with oxidation level is largely because (1) SOAs formed from smaller precursor
\end{abstract}

molecules tend to be more oxidized and have lower average molecular weight and (2) during oxidation, fragmentation reactions reduce average organic molecule weight, leading to increased hygroscopicity. A simple model of organic hygroscopicity based on molecular weight, oxidation level, and volatility is developed, and it successfully reproduces the variation in SOA hygroscopicity with oxidation level observed in the laboratory and field studies.

\section{Introduction}

A prerequisite for cloud formation, aerosol particles strongly impact global climate by influencing the properties of clouds (Twomey, 1977; Albrecht, 1989). These effects, named aerosol indirect effects, represent one of the largest uncertainties in the simulated change of global radiation fluxes (i.e., radiative forcing) due to the increase in aerosol concentration since the preindustrial era (IPCC, 2013). An accurate assessment of the aerosol indirect effects requires the knowledge of the concentration of cloud condensation nuclei (CCN), a subset of aerosol particles that can activate and 
form cloud droplets in the atmosphere. The efficiency with which particles activate and transform into cloud droplets depends on particle size and the hygroscopicity parameter $\kappa$ (Petters and Kreidenweis, 2007), which combines a number of thermodynamic properties of the species within the particles to describe the tendency of the particles to uptake water. It is worth noting that the value of the hygroscopicity parameter $\kappa$ may vary with relative humidity. The $\kappa$ values examined in this study are at droplet activation under supersaturated conditions, and they may be different from those under subsaturated conditions associated with particle hygroscopic growth.

The inorganic fraction of atmospheric aerosol particles typically consists of a very limited number of species, e.g., sulfate and nitrate, whose hygroscopicities are well studied (Petters and Kreidenweis, 2007). However, atmospheric particles often consist, in addition to inorganic species, of hundreds or even thousands of organic species (Zhang et al., 2007). Collectively, these organic species often dominate the composition of sub-micrometer aerosol particles, which represent the majority of $\mathrm{CCN}$ population. These organic species in ambient particles have a wide range of hygroscopicity parameters, from zero for hydrophobic organics to as high as 0.3 for some of the water-soluble organics (e.g., Petters et al., 2009; Moore et al., 2012; Lathem et al., 2013). Modeling studies show that CCN concentrations can be a strong function of the hygroscopicity of organics in the particles (e.g., McFiggans et al., 2006; Mei et al., 2013). This is particularly true for modeling cloud formation during the preindustrial era, when organics represented an even larger fraction of the submicron aerosol mass concentration due to the low concentration of anthropogenic sulfate (Mei et al., 2013; Liu and Wang, 2010). Neglecting the variation in the organic hygroscopicity may lead to substantial bias in modeled aerosol indirect forcing, which represents a change in radiation flux due to the increased aerosol concentration since the preindustrial era (Liu and Wang, 2010).

Several studies show that for ambient organic aerosols and laboratory-generated secondary organic aerosols (SOAs), the organic hygroscopicity parameter increases nearly linearly with the atomic O : C ratio (e.g., Jimenez et al., 2009; Lambe et al., 2011), a parameter commonly used to quantify the oxidation level of organics. For single component aerosols and simple mixtures, the effect of increasing oxidation level on water solubility and in turn hygroscopicity is well established (Petters et al., 2009, 2016; Rickards et al., 2013; Kuwata et al., 2013). Water solubility is defined as the amount of solute that can dissolve in water at saturation, corresponding to solid-aqueous solution equilibrium. Miscibility is related to solubility and refers to the ability of two liquid phases to mix. Miscibility limitation leads to liquid-liquid phase separation (LLPS). If LLPS occurs under supersaturated conditions, miscibility can exert control on droplet activation similar to that of water solubility (Petters et al., 2006, 2016) and is further discussed in a later section. Kuwata et al. (2013) show that for single organic compounds, water solubility generally increases with $\mathrm{O}: \mathrm{C}$. One plausible explanation is that as organic molecules become increasingly oxidized (i.e., increased $\mathrm{O}: \mathrm{C}$ ratio), they are more polar, leading to increased water solubility. As $\mathrm{O}: \mathrm{C}$ increases from near zero, the regime for the activation of single organic compound transitions from insoluble to slightly soluble and then to highly soluble, leading to a general increasing trend in hygroscopicity parameter (Kuwata et al., 2013). In the highly soluble regime, the hygroscopicity parameter is no longer limited by water solubility but controlled mainly by molecular weight instead (e.g., Kuwata et al., 2013). Nakao (2017) modeled the hygroscopicity of secondary organic species, and the results suggest the increase in organic hygroscopicity with $\mathrm{O}: \mathrm{C}$ is likely due to a combination of both increased water solubility and variation in volatility that determines the molecular size of dissolved solute. Riipinen et al. (2015) examined cloud activation of multicomponent organic particles theoretically and suggested that the organic hygroscopicity parameter is strongly influenced by the distributions of species with water solubility between 0.1 and $100 \mathrm{~g} \mathrm{~L}^{-1}$, i.e., the range for slightly soluble species. Whereas all the above studies suggest that the hygroscopicity parameter is strongly influenced by water solubility of slightly soluble organics, for ambient organic aerosols and laboratory-generated SOAs, the influence of water solubility on organic hygroscopicity has not been systematically examined experimentally, and the underlying mechanism for the increasing hygroscopicity with increasing $\mathrm{O}: \mathrm{C}$ remains unclear. In this study, we designed and carried out experiments to explicitly examine the mechanism by which changes in $\mathrm{O}: \mathrm{C}$ ratio lead to variations in organic hygroscopicity. This was achieved by systematically varying the water content of activating droplets to examine the impact of water solubility on the effective hygroscopicity of SOAs, which were generated in an environmental chamber from representative precursors under a range of atmospherically relevant conditions. We show that for many SOAs, essentially all organics are dissolved at the point of activation. Therefore, for droplet activation, organic hygroscopicity is not limited by solubility but is controlled mainly by the molecular weight of organic species in particles. Instead of increased solubility, the increase in the organic hygroscopicity with $\mathrm{O}: \mathrm{C}$ is largely because (a) SOAs formed from smaller volatile organic compound (VOC) molecules tend to have lower average molecular weight and higher $\mathrm{O}: \mathrm{C}$, and (b) during oxidation fragmentation reactions lead to smaller organic molecules with lower molecular weight and higher $\mathrm{O}: \mathrm{C}$. 


\section{Methods}

\subsection{Experiments}

SOAs were generated in a steady-state environmental chamber (Shilling et al., 2008) from representative VOCs, including isoprene, $\alpha$-pinene, $\Delta-3$ carene, $\beta$-caryophyllene, and toluene. Dry ammonium sulfate particles of $50 \mathrm{~nm}$ were classified by a differential mobility analyzer (DMA) and introduced as seed particles along with the VOC into the chamber. The reaction of the VOCs with oxidants led to formation of secondary organic species, which condensed on the ammonium sulfate seed particles, leading to particle growth. No new particle formation was observed during the experiments. The experimental setup and conditions are detailed in the Supplement. Given the distribution of particle residence time inside the steady-state chamber, particles exit the chamber with a range of particle sizes (Shilling et al., 2008) and hence sulfate volume fractions. The particles were sampled with a size-resolved CCN system (Mei et al., 2013), in which they were first size selected by a DMA. The total number and $\mathrm{CCN}$ concentrations of the size-selected particles were simultaneously measured by a condensation particle counter and a CCN counter, respectively. These measured number concentrations yielded the activation spectrum, i.e., the fraction of particles serving as $\mathrm{CCN}$ as a function of supersaturation, which was then used to derive particle hygroscopicity $\kappa$ based on $\kappa$-Köhler theory (Mei et al., 2013; Petters and Kreidenweis, 2007). Given that all particles were grown on seed particles of essentially the same diameter, the hygroscopicities of SOA particles with different sulfate volume fractions were characterized by size selecting particles of different final diameters.

\subsection{Derivation of effective organic hygroscopicity}

Because no new particle formation was observed, and measured particles were larger than the initial seed particle size, particles exiting the chamber are assumed to be an internal mixture (i.e., at any given size, particles of the same diameter have essentially the same composition). For internal mixtures, particle hygroscopicity $\kappa$ is given by the volume average of participating species (Petters and Kreidenweis, 2007):

$\kappa=x_{\mathrm{org}} \kappa_{\mathrm{org}}+x_{\mathrm{AS}} \kappa_{\mathrm{AS}}=\left(1-x_{\mathrm{AS}}\right) \kappa_{\mathrm{org}}+x_{\mathrm{AS}} \kappa_{\mathrm{AS}}$,

where $x_{\mathrm{org}}$ and $x_{\mathrm{AS}}$ are the dry volume fractions of organics and ammonium sulfate, respectively, and $\kappa_{\mathrm{org}}$ and $\kappa_{\mathrm{AS}}$ are the hygroscopicity parameters of the organics and ammonium sulfate (0.61), respectively. Equation (1) implies an ideal Zdanovskii, Stokes, and Robinson (ZSR) mixing. We note that $\kappa_{\text {org }}$ represents the apparent organic hygroscopicity (Sullivan et al., 2009), also referred to as the effective hygroscopicity (Pringle et al., 2010). This effective hygroscopicity includes the overall impact of the organics on particle activation, including water solubility (Sullivan et al., 2009). The value of $x_{\mathrm{AS}}$ is given by $\left(D_{\mathrm{p} 0} / D_{\mathrm{p}}\right)^{3}$, where $D_{\mathrm{p} 0}$ and $D_{\mathrm{p}}$ are the dry diameters of initial ammonium sulfate seeds $(50 \mathrm{~nm})$ and size-selected particles exiting the chamber, respectively. The value of $\kappa_{\text {org }}$ can then be derived from measured particle hygroscopicity $\kappa$ and sulfate volume fraction $x_{\mathrm{AS}}$ using Eq. (1). A small fraction of the seeds were doubly charged and had diameters larger than $50 \mathrm{~nm}$. For the derivation of $\kappa_{\text {org }}$, particles grown from doubly charged seeds are taken into consideration using an approach described in the Supplement.

\subsection{Uncertainty of derived effective organic hygroscopicity}

As organic particles formed by condensational growth of ammonium sulfate seeds are spherical (Zelenyuk et al., 2008), no shape factor correction is necessary for the derivation of particle $\kappa$ from the measured particle sizes. The impact of coagulation is minor under the experimental conditions. The value of $\kappa_{\text {org }}$ was derived from Eq. (1); therefore its uncertainty derives from the uncertainties of particle $\kappa$ and sulfate volume fraction. As particle $\kappa$ was derived from the activation spectrum (the variation in activated fraction as a function of supersaturation) of size-selected particles, the uncertainty in particle $\kappa$ can be attributed to the uncertainties in particle size, supersaturation of CCN counter, and activation fractions. The uncertainty in sulfate volume fraction derives from the uncertainties in the mode diameters of ammonium sulfate seeds and grown particles size selected for CCN measurements.

Given the steps involved in the derivation of $\kappa_{\text {org }}$, it is difficult to obtain the uncertainty of $\kappa_{\text {org }}$ analytically through error propagation. Instead, the uncertainty was calculated numerically using a Monte Carlo approach described as follows. The CCN counter supersaturation, activation fraction, and the mode diameters of ammonium sulfate seeds and grown particles size selected for $\mathrm{CCN}$ measurements were randomly chosen from normal distributions with respective mean values and standard deviations. These randomly chosen parameters were then used to calculate $\kappa_{\text {org }}$ following the method described above. The above calculation was repeated 100 times, and the uncertainty of $\kappa_{\text {org }}$ was derived from the distribution of the $100 \kappa_{\mathrm{org}}$ values. The distribution of CCN counter supersaturation was assumed to be a normal distribution, and the mean and standard deviation of the distribution were derived from the repeated calibration values. The mode diameter of ammonium sulfate seeds, the mode diameter of grown particles size selected for $\mathrm{CCN}$ measurements, and the activated fraction were assumed to have normal distributions with standard deviations of $1 \%, 1 \%$, and $5 \%$ of the mean values, respectively. 


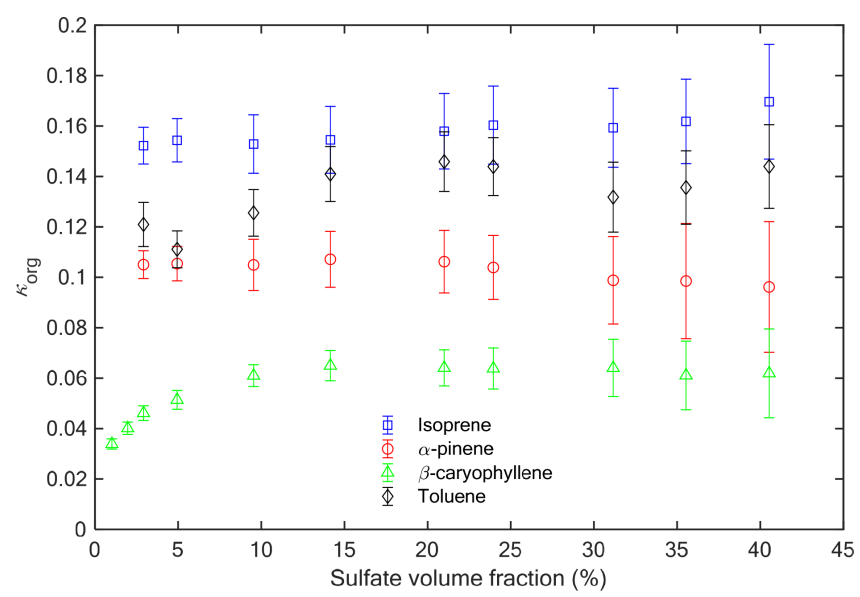

Figure 1. Effective organic hygroscopicity $\kappa_{\mathrm{org}}$ as a function of particle sulfate volume fraction for secondary organic aerosols formed from isoprene $\left(68 \mathrm{~g} \mathrm{~mol}^{-1}\right), \alpha$-pinene $\left(136 \mathrm{~g} \mathrm{~mol}^{-1}\right), \beta$ caryophyllene $\left(204 \mathrm{~g} \mathrm{~mol}^{-1}\right)$, and toluene $\left(92 \mathrm{~g} \mathrm{~mol}^{-1}\right)$. The error bar represents the uncertainty $(1 \sigma)$ of the effective organic hygroscopicity derived from size-resolved $\mathrm{CCN}$ measurements.

\section{Results and discussions}

\subsection{Effective organic hygroscopicity for secondary organic aerosols formed on sulfate seeds}

The effective organic hygroscopicity $\kappa_{\text {org }}$ was derived from the overall $\kappa$ of particles for a range of final particle sizes (i.e., sulfate volume fractions). The variation in $\kappa_{\mathrm{org}}$ with $x_{\mathrm{AS}}$ is shown in Fig. 1 for SOA formed from representative VOC precursors, including isoprene, $\alpha$-pinene, $\beta$-caryophyllene, and toluene. We note that isoprene is the most abundant non-methane hydrocarbon, $\alpha$-pinene and $\beta$-caryophyllene are the most abundant natural monoterpene and sesquiterpene species globally, and toluene is a representative anthropogenic SOA precursor (Pye et al., 2010; Guenther et al., 2012). The uncertainty of the derived $\kappa_{\text {org }}$ was estimated using a Monte Carlo method based on the uncertainties in the $\mathrm{CCN}$ counter supersaturation, measured activated fraction, and mode diameters of size-selected particles and the ammonium sulfate seeds (see Supplement for details). Figure 1 shows that $\kappa_{\mathrm{org}}$ is essentially independent of $x_{\mathrm{AS}}$ for SOA formed from isoprene, $\alpha$-pinene, and toluene, while it decreases with decreasing $x_{\mathrm{AS}}$ below $15 \%$ for SOA formed from $\beta$-caryophyllene. The constant $\kappa_{\mathrm{org}}$ with $x_{\mathrm{AS}}$ for isoprene SOA agrees with the results from an earlier study (King et al., 2010), and the $\kappa_{\text {org }}$ values for isoprene and $\alpha$ pinene SOA are consistent with the values reported in earlier studies (e.g., Kuwata et al., 2013). The effective organic hygroscopicity and its variation with $x_{\mathrm{AS}}$ were also examined for SOA formed from $\alpha$-pinene and $\Delta-3$ carene under a variety of conditions (Fig. S1, details given in the Supplement). Again, the results show that $\kappa_{\text {org }}$ is essentially independent of $x_{\mathrm{AS}}$. A nearly constant $\kappa_{\text {org }}$ indicates that cloud droplet acti-

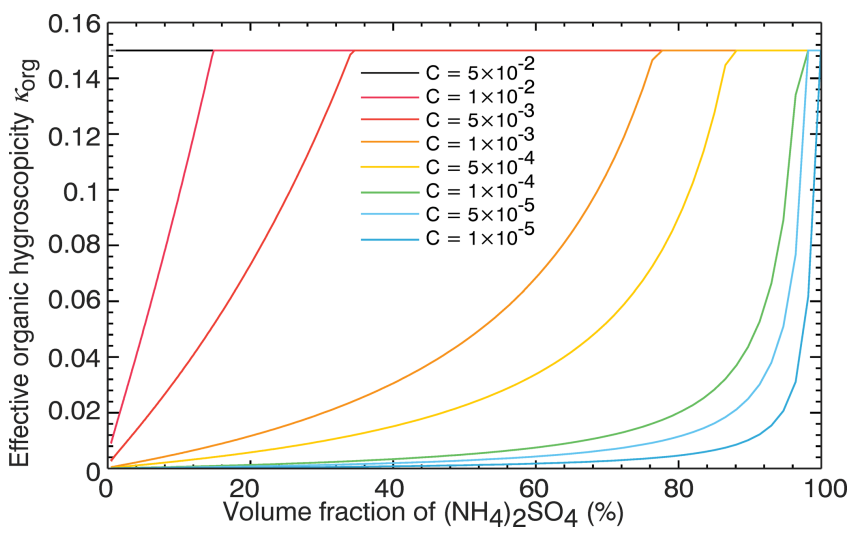

Figure 2. Simulated effective organic hygroscopicity for particles grown from $50 \mathrm{~nm}$ dry ammonium sulfate seeds by condensation of secondary organic species with $\kappa_{\text {org,intr }}=0.15$. The effective organic hygroscopicity is shown as a function of dry sulfate volume fraction for organic solubility $C$ ranging from $1 \times 10^{-5}$ to $5 \times 10^{-2}$.

vation of the particles is not limited by organic water solubility because otherwise we would have observed a dependence on $x_{\mathrm{AS}}$ as explained below.

\subsection{Effect of water solubility on droplet activation of organic particles}

Following the same definition as in Sullivan et al. (2009), we introduce the intrinsic hygroscopicity $\kappa_{\text {org,intr, }}$, which represents the organic hygroscopicity if a compound is fully dissolved at the point of the activation (i.e., peak of the Köhler curve). The intrinsic hygroscopicity parameter of a compound at droplet activation can be estimated from (Sullivan et al., 2009)

$\kappa_{\mathrm{org}, \mathrm{intr}}=\frac{i \rho_{\mathrm{org}} M_{\mathrm{w}}}{\rho_{\mathrm{w}} M_{\mathrm{org}}}$,

where $\rho$ is the density, $M$ is the molecular weight, and $i$ is the van't Hoff factor. The subscripts "org" and " $w$ " represent organics and water, respectively. If the organic species are completely dissolved at the point of activation, the values of $\kappa_{\text {org }}$ and $\kappa_{\text {org,intr }}$ are equal. For particles consisting of compounds with limited solubility, $\kappa_{\text {org }}$ may exhibit a lower value than $\kappa_{\text {org,intr. }}$.

Figure 2 shows the effective organic hygroscopicity $\kappa_{\text {org }}$ simulated for particles composed of ammonium sulfate seed and a model organic compound with $\kappa_{\text {org,intr }}$ of 0.15 . Same as the particles sampled during the experiments, modeled particles are assumed to have a sulfate core with a diameter of $50 \mathrm{~nm}$. The value of $\kappa_{\mathrm{org}}$ was simulated for particles with different organic coating thicknesses and therefore $x_{\mathrm{AS}}$. The simulation was carried out for a range of organic water solubility $C$, from $5 \times 10^{-2}$ (i.e., moderately soluble) to $1 \times 10^{-5}$ (i.e., effectively insoluble; Petters and Kreidenweis, 2008). Here the solubility $C$ is defined as the volume 
of compound per unit volume of water (Petters and Kreidenweis, 2008). For organics with $C$ of $1 \times 10^{-2}$ or lower (sparingly soluble species), simulated $\kappa_{\text {org }}$ exhibits a value close to zero at $1 \% x_{\mathrm{AS}}$ due to the limitation of solubility. The $\kappa_{\text {org }}$ value increases with increasing $x_{\mathrm{AS}}$ and eventually reaches a plateau at the value of $\kappa_{\text {org,intr }}$ (i.e., 0.15), at which point droplet activation is no longer limited by organics solubility. Sparingly soluble organics with higher $C$ reach the plateau at a lower $x_{\mathrm{AS}}$. When $C \geq 5 \times 10^{-2}$, the effective organic hygroscopicity $\kappa_{\text {org }}$ is 0.15 at all $x_{\mathrm{AS}}$ values, indicating the organic compound becomes completely dissolved at the point of activation and droplet activation is not limited by organic solubility even for "pure" organic particles (i.e., $x_{\mathrm{AS}}=0 \%$ ). This is consistent with the classification scheme that divides the aerosol into effectively soluble, sparingly soluble, and effectively insoluble (Petters and Kreidenweis, 2008). For $10^{-4}<C<0.05$, the organic compound is sparingly soluble and $x_{\mathrm{AS}}$ controls the value of $\kappa_{\mathrm{org}}$. This is because the water uptake by ammonium sulfate increases the amount of water in the growing droplet that is available for solvation of organics. Examples of the Köhler curve for the mixtures are shown in the Supplement (Fig. S6). Even for compounds with a very low solubility of $10^{-4}$ that are effectively insoluble when considering pure organic particles, they are completely dissolved at the point of activation for mixtures with $\sim 96 \%$ or more sulfate by volume. Atmospheric organic aerosols consist of many components with different solubilities. If the model is initialized with a distribution of solubilities (Riipinen et al., 2015 and Supplement) that are centered at the same values as those shown in Fig. 2, the general behavior exhibited in Fig. 2 is retained, whereas the sparingly soluble range is shifted toward lower solubilities (Fig. S7).

\subsection{Comparison of observed and calculated dependence of $\kappa_{\text {org }}$ on sulfate volume fraction}

The simulated variation in $\kappa_{\text {org }}$ with $x_{\mathrm{AS}}$ for sparingly soluble organics above is in clear contrast to the experimental results of monoterpene, isoprene, and toluene SOAs that show an essentially constant $\kappa_{\text {org }}$ for a wide range of $x_{\mathrm{AS}}$ values. The essentially constant $\kappa_{\text {org }}$ is consistent with the simulated cases for more soluble organics (i.e., $C$ value of 0.05 and larger), suggesting that the effective organic hygroscopicity $\kappa_{\text {org }}$ is the same, or at least very close to, the intrinsic hygroscopicity $\kappa_{\text {org,intr }}$ for mixtures with $x_{\mathrm{AS}}$ as low as $3 \%$. As ambient particles typically consist of more than $3 \%$ highly soluble species such as sulfate or nitrate by volume, this suggests that for ambient particles, most secondary organic species formed from common precursors including isoprene, $\alpha$-pinene, and toluene are completely dissolved at the point of activation; therefore their hygroscopicity is not limited by water solubility. We note that SOA formed from $\beta$-caryophyllene, whose droplet activation exhibits solubility limitation when $x_{\mathrm{AS}}<15 \%$, represents a relatively minor contribution to or- ganic aerosol globally. In addition, most ambient aerosols consist of $15 \%$ or more of highly water-soluble inorganic species. It is also worth noting that $\kappa_{\text {org }}$ of $\alpha$-pinene SOA in this study is within the range of previously reported $\kappa_{\mathrm{org}}$ values derived from $\alpha$-pinene SOA particles formed without inorganic seeds (e.g., Alfarra et al., 2013; Zhao et al., 2016), suggesting that even for some pure SOA particles, most organic species are dissolved at the point of activation, and the limitation of hygroscopicity by water solubility is negligible. Table 1 lists the intrinsic hygroscopicity derived using Eq. (1) for major monoterpene SOA species. Here we assume organic molecules in SOA do not dissociate when dissolved in water; therefore $i=1$ (Ervens et al., 2005). The assumption of $i=1$ is valid only under conditions of high dilution in water, such as at droplet activation under supersaturated conditions. For most of these compounds, the intrinsic hygroscopicity is consistent with $\kappa_{\text {org }}$ derived from $\alpha$ pinene experiments, again suggesting that the droplet activation of $\alpha$-pinene SOA is not limited by organic water solubility. We note that SOA may consist of a substantial number of oligomers (Kalberer et al., 2004). It is not clear whether these oligomers dissociate in growing droplets during activation. If not, the formation of oligomers would lead to a lower $\kappa_{\text {org }}$ as a result of increased molecular weight. Therefore, the

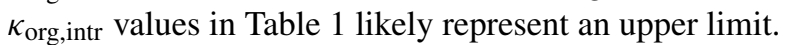

For SOA formed from $\beta$-caryophyllene, $\kappa_{\text {org }}$ showed lower values when $x_{\mathrm{AS}}$ is less than $15 \%$. This is consistent with simulated trends for sparingly soluble organics, suggesting only a fraction of organics are dissolved at the point of activation, and the droplet activation of $\beta$-caryophyllene SOA in our study is limited by the organic solubility at low $x_{\mathrm{AS}}$. This may be due to lower solubility of $\beta$-caryophyllene SOAs than those formed from $\alpha$-pinene, $\Delta-3$ carene, isoprene, and toluene because of the larger precursor molecule. The extrapolation of the data points suggests a $\kappa_{\text {org }}$ of $\sim 0.03$ for $\beta$-caryophyllene SOA formed without ammonium sulfate seeds, consistent with the low values (i.e., $0 \leq \kappa_{\text {org }} \leq 0.05$ ) reported by earlier studies (Asa-Awuku et al., 2009; Frosch et al., 2013).

We note particles may undergo LLPS instead of a solubility transition (Bertram et al., 2011; Zuend and Seinfeld, 2012). Solubility refers to the amount of material present in the saturated solution. For an initially dry particle, solubility and water activity of the saturated solution will control the size and relative humidity at which pure crystalline substances spontaneously dissolve (Shulman et al., 1996; Hori et al., 2003; Bilde and Svenningsson, 2004; Petters and Kreidenweis, 2008). For particles that include sparingly soluble compounds, the dissolution occurs in the supersaturated regime and thereby exerts some control over the critical supersaturation. This gives rise to strong sensitivity of $\kappa_{\text {org }}$ with an increasing inorganic fraction. Miscibility is related to solubility and refers to the ability of two liquid phases to mix. Substances that form two liquid phases are immiscible. If a miscibility transition occurs in the supersaturated regime, 
Table 1. The molecular formula, molecular weight, density, and intrinsic organic hygroscopicity derived using Eq. (2) for major monoterpene SOA products. The density was calculated from $\mathrm{O}: \mathrm{C}$ and $\mathrm{O}: \mathrm{H}$ values (Kuwata et al., 2012).

\begin{tabular}{llrrr}
\hline $\begin{array}{l}\text { Major monoterpene } \\
\text { SOA products }\end{array}$ & $\begin{array}{l}\text { Molecular } \\
\text { formula }\end{array}$ & $\begin{array}{r}\text { Molecular weight } \\
\left(\mathrm{g} \mathrm{mole}^{-1}\right)\end{array}$ & $\begin{array}{r}\text { Density } \\
\left(\mathrm{g} \mathrm{cm}^{-3}\right)\end{array}$ & $\kappa_{\text {org,intr }}$ \\
\hline Pinonaldehyde & $\mathrm{C}_{10} \mathrm{H}_{16} \mathrm{O}_{2}$ & 168 & 1.06 & 0.11 \\
Pinic acid & $\mathrm{C}_{9} \mathrm{H}_{14} \mathrm{O}_{4}$ & 186 & 1.24 & 0.12 \\
Pinonic acid & $\mathrm{C}_{10} \mathrm{H}_{16} \mathrm{O}_{3}$ & 184 & 1.13 & 0.11 \\
Norpinonic acid & $\mathrm{C}_{9} \mathrm{H}_{14} \mathrm{O}_{3}$ & 170 & 1.17 & 0.12 \\
3-Oxo-pina ketone & $\mathrm{C}_{7} \mathrm{H}_{8} \mathrm{O}_{2}$ & 124 & 1.27 & 0.18 \\
Limonic acid & $\mathrm{C}_{9} \mathrm{H}_{14} \mathrm{O}_{4}$ & 186 & 1.24 & 0.12 \\
Limonaldehyde & $\mathrm{C}_{9} \mathrm{H}_{14} \mathrm{O}_{2}$ & 154 & 1.09 & 0.13 \\
7-Hydroxylimonic acid & $\mathrm{C}_{10} \mathrm{H}_{16} \mathrm{O}_{4}$ & 180 & 1.20 & 0.12 \\
\hline
\end{tabular}

miscibility limitations exert a control over critical supersaturation similar to that of solubility (Petters et al., 2006, 2016); i.e., the effective hygroscopicity $\kappa_{\text {org }}$ observed from $\mathrm{CCN}$ activation is reduced at lower net water contents (smaller size or less hygroscopic material present). In essence, the presence of undissolved organics can be considered a special case of LLPS (i.e., the undissolved organics form the second phase). Distinguishing between miscibility and solubility in CCN experiments is not possible because the manifestation of the effect is identical.

In general, SOA precursors are weakly oxidized hydrocarbons. These hydrocarbons are liquid if present in the condensed phase and immiscible with water. Oxidation of the precursor adds functional groups to the compounds. These functional groups lower the vapor pressure and increase viscosity (Rothfuss and Petters, 2017), density (Kuwata et al., 2012), and miscibility (Petters et al., 2016). Model calculations and experimental data suggest that adding a few hydroxyl and/or carboxylic acid groups is enough to remove miscibility limitations (Bertram et al., 2011; Petters et al., 2016) for pure organic compounds at water activity corresponding to supersaturated conditions, consistent with the results from our experiments.

The above analysis is based on $\kappa$-Köhler theory, in which the hygroscopic parameter $\kappa$ is derived assuming the surface tension of water for activating droplets. Surface active compounds may reduce the surface tension, potentially altering the mechanism by which $\mathrm{CCN}$ activation proceeds. However, surface active compounds preferentially concentrate on the droplet surface, leading to their depletion in the droplet bulk. As a result, a reduced Raoult's effect increases equivalent water vapor pressure, compensating for the reduced water vapor pressure due to lower surface tension. While surfactants may strongly influence the shape of the Köhler curve and therefore droplet growth kinetics (Ruehl et al., 2016), their impact on the effective hygroscopicity parameter is likely minor for most mixtures (Sorjamaa et al., 2004; Prisle et al., 2010; Forestieri et al., 2018; Nakao, 2017; Topping, 2010), even for very strong surfactants (Petters and Petters, 2016). Here, the main question is whether it is plausible that the interfacial mechanism can exactly compensate for the predicted solubility effects reported in Fig. 2, such that the net result would be the constant $\kappa_{\text {org }}$ value as a function of $x_{\mathrm{AS}}$ reported in Fig. 1. Such hypothetical compensation cannot be replicated using theory that includes surface and bulk partitioning (see Supplement). However, we note that the interplay of solubility, LLPS, and surface tension during activation remains poorly understood. Several new mechanisms have been proposed (Ruehl et al., 2016; Noziere et al., 2014; Ovadnevaite et al., 2017) although limited data are available to test these to date. A discussion of these new mechanisms is given in the Supplement. Until evidence is presented to the contrary, we expect that exact compensation between solubility limitations and an interfacial mechanism resulting in constant $\kappa_{\text {org }}$ vs. $x_{\mathrm{AS}}$ is unlikely.

\subsection{Potential causes for the lack of solubility limitation on the droplet activation of SOA particles}

As shown by the simulations above and earlier studies (e.g., Riipinen et al., 2015), water solubility can substantially influence the CCN activation for sparingly soluble compounds with $10^{-4}<C<0.05$. The number of sparingly soluble species dissolved at the point of activation and therefore the effective hygroscopicity are sensitive to the water solubility, inorganic volume fraction, and particle size (Bilde and Svenningsson, 2004). Because the solubility of some major monoterpene SOA products (e.g., Pinonic acid has a solubility of $5.5 \times 10^{-3}$; Kuwata et al., 2013) falls within this range, it is surprising that $\kappa_{\mathrm{org}}$ is independent of $x_{\mathrm{AS}}$ and droplet activation is not limited by organic water solubility for SOA particles with $x_{\mathrm{AS}}$ as low as $3 \%$. Why might this be the case?

First, SOA is a mixture of hundreds of organic compounds, some of which are sufficiently water soluble. Similar to ammonium sulfate, water uptake by these water-soluble organics increases the amount of water in the growing droplet that is available for solvation of organics with low water solubility. Such an effect is evident from the simulated $\kappa_{\text {org }}$ for particles consisting of organics with a distribution of solubilities (Supplement, Fig. S7). It is also worth noting 
that based on the $\mathrm{O}: \mathrm{C}$ value of 0.33 , the solubility of $\beta$ caryophyllene SOA is estimated as $7.5 \times 10^{-4}$ (Kuwata et al., 2013). The measured variation in $\kappa_{\mathrm{org}}$ with $x_{\mathrm{AS}}$ for $\beta$ caryophyllene SOA is broadly consistent with the simulated trend for mixtures with a distribution of water solubilities shown in Fig. S7. Second, the lack of solubility limitation may be partially due to the non-ideality of the mixtures in the particle organic phase. For example, in a mixture of noninteracting solids, because the chemical potential of undissolved components is the same as pure compounds, the components behave independently of one another (i.e., solubility is not affected by the presence of other solids, and the dissolution behavior of each species is the same as their behavior as pure components). This is in essence the second case described in Riipinen et al. (2015) (i.e., $\gamma_{i} Y_{i \text {,wet }}=1$ ). As secondary organic aerosols consist of a large number of compounds, the mass of each compound may be sufficiently small to completely dissolve at the point of activation. Third, bulk solubility values such as that quoted for pinonic acid are referenced against a pure crystalline reference state. These values are likely not applicable for the complex multicomponent SOA mixtures in which compounds are present in an amorphous phase state (Shiraiwa et al., 2017). We note that potential miscibility limitations due to LLPS could still apply to an amorphous phase state. The amorphous phase state may either be the thermodynamic stable state (Marcolli et al., 2004) or a metastable state that formed because the nucleation step required for crystallization did not occur, even though the particle is dry (Mikhailov et al., 2009). Upon humidification of the amorphous particle in a metastable state, sparingly soluble compounds can freely partition into the liquid phase, and water uptake is continuous without the firstorder phase transition (e.g., Kuwata et al., 2013). Thus, the effect of sudden dissolution of a crystalline state at the saturated solution, which underlies the solubility theory used to construct Fig. 2, does not apply.

\subsection{Causes for the increasing effective organic hygroscopicity with oxidation level}

Because isoprene and monoterpenes represent major biogenic SOA precursors and toluene is among the major precursors of anthropogenic SOA, the lack of solubility limitation on $\mathrm{CCN}$ activation shown above suggests that the increase in SOA $\kappa_{\text {org }}$ with increasing $\mathrm{O}: \mathrm{C}$ observed in both laboratory and field studies is unlikely due to an increase in polarity and solubility for the more oxidized organic compounds. As SOAs formed in our chamber experiments have $\mathrm{O}: \mathrm{C}$ closely resembling fresh, unaged SOA reported in the field measurements, and are already fully dissolved at the point of activation, we expect the CCN activation is not limited by solubility for more oxidized SOA with a higher $\mathrm{O}: \mathrm{C}$ ratio (i.e., more polar organic molecules). The $\mathrm{O}: \mathrm{C}$ values for SOA examined in this study are listed in Table S1 of the Supplement. In the absence of solubility limitation, $\kappa_{\text {org }}$ is es-

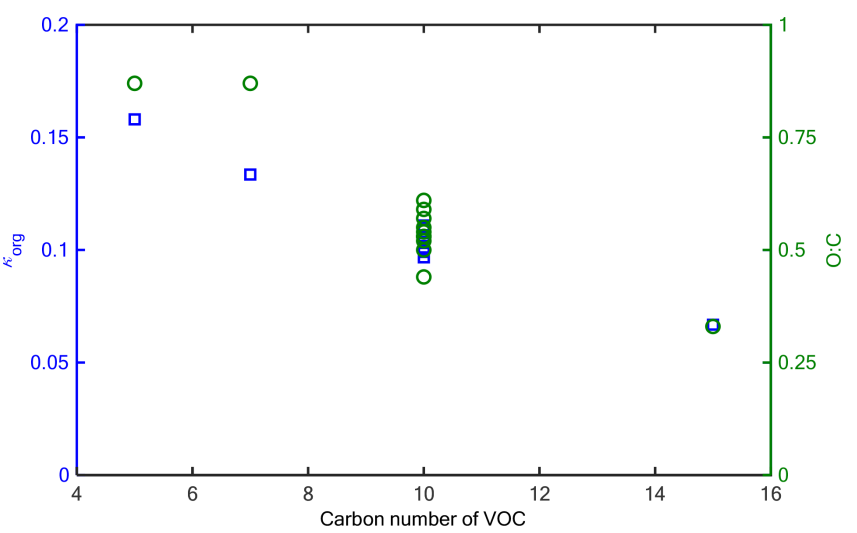

Figure 3. $\kappa_{\text {org }}$ (blue square) and $\mathrm{O}: \mathrm{C}$ (green circle) as a function of precursor VOC carbon number for SOA formed from isoprene, monoterpene, $\beta$-caryophyllene, and toluene in this study. For $\beta$ caryophyllene SOA, $\kappa_{\text {org }}$ is the average value when $x_{\mathrm{AS}}$ is larger than $15 \%$ (i.e., when droplet activation is not limited by the solubility of $\beta$-caryophyllene SOA).

sentially the same as $\kappa_{\text {org,intr }}$ and is controlled mainly by molar volume (Eq. 2). This has been shown by earlier studies for pure organic compounds with sufficient solubility (Petters et al., 2009, 2016; Kuwata et al., 2013). As shown by Kuwata et al. (2013), the variation in organic density with $\mathrm{O}: \mathrm{C}$ is relatively weak and cannot explain the variation in $\kappa_{\text {org }}$. For example, the density of the SOA examined in this study varied by approximately $30 \%$ from 1.12 to $1.49 \mathrm{~g} \mathrm{~cm}^{-3}$, whereas $\kappa_{\text {org }}$ varies by more than a factor of 2 , from 0.07 to 0.16 . Given the relatively narrow range of SOA density, the increasing $\kappa_{\text {org }}$ with $\mathrm{O}$ : C suggests a negative correlation between the molecular weight and $\mathrm{O}: \mathrm{C}$ for secondary organic species. Such negative correlation is likely due to the following two reasons. First, secondary organic species formed from smaller precursor VOCs tend to have a lower molecular weight, and they need to be more oxidized (i.e., higher $\mathrm{O}: \mathrm{C})$ such that their volatilities are sufficiently reduced for effectively partitioning into the particle phase. The lower carbon number for SOA species formed from smaller VOCs also contributes to an increased $\mathrm{O}: \mathrm{C}$ ratio. This trend is evident from Fig. 3, which shows both $\mathrm{O}: \mathrm{C}$ and $\kappa_{\text {org }}$ are negatively correlated with carbon number of precursors for SOA examined in this study. This trend is also consistent with the negative correlation between SOA hygroscopic growth factor and the precursor molecular weight observed in a previous study (Varutbangkul et al., 2006).

Second, there are several processes, including functionalization, fragmentation, and oligomerization, during the aging of SOA. Lambe et al. (2011) studied $\kappa_{\mathrm{org}}$ of SOA generated in laboratory experiments from 14 atmospherically representative biogenic and anthropogenic VOCs. They found that for SOA formed from the same VOC, increased $\mathrm{OH}$ exposure leads to SOA with a higher $\kappa_{\text {org }}$ and O: C. Such an increase in $\kappa_{\text {org }}$ with $\mathrm{O}: \mathrm{C}$ for SOA generated from the 
same VOC may be partially due to fragmentation, which leads to molecules with increased $\mathrm{O}: \mathrm{C}$ and lower molecular weight; therefore a higher $\kappa_{\text {org }}$ value (Eq. 2). This process likely contributes to the increasing $\kappa_{\text {org }}$ with $\mathrm{O}: \mathrm{C}$ observed for ambient aerosols as well. Insights into chemical mechanisms during oxidation can be obtained by examining the Van Krevelen diagram (Heald et al., 2010), which shows the variation in $\mathrm{H}: \mathrm{C}$ as a function of $\mathrm{O}: \mathrm{C}$. Lambe et al. (2011) showed that as $\mathrm{OH}$ exposure increases, the variation in $\mathrm{H}: \mathrm{C}$ vs. $\mathrm{O}: \mathrm{C}$ largely follows a line with a slope close to -0.5 for SOA formed from $\alpha$-pinene, $\beta$-pinene, toluene, $m$-xylene, and mesitylene in an oxidation flow reactor. For SOA formed from VOC of larger molecular weight such as $n$-decane, $n$-heptadecane, and diesel fuel, the slope of $(\Delta \mathrm{H}: \mathrm{C}) /(\Delta \mathrm{O}: \mathrm{C})$ is about -0.5 when the $\mathrm{O}: \mathrm{C}$ ratio is above $\sim 0.5$, whereas the slope is steeper for $\mathrm{O}: \mathrm{C}$ below 0.5 . $\mathrm{Ng}$ et al. (2011) also found the variation in $\mathrm{H}: \mathrm{C}$ vs. O : C follows a $(\Delta \mathrm{H}: \mathrm{C}) /(\Delta \mathrm{O}: \mathrm{C})$ slope of -0.5 for ambient secondary organic aerosols measured at all sites examined in that study. $\mathrm{A}(\Delta \mathrm{H}: \mathrm{C}) /(\Delta \mathrm{O}: \mathrm{C})$ slope of -0.5 is consistent with the addition of a carboxylic acid group to the site of a C-C bond cleavage (Kroll et al., 2009). The net effect would be to replace a $-\mathrm{CH}_{2}$ group with a $-\mathrm{COOH}$ group, resulting in a slope of -0.5 for $(\Delta \mathrm{H}: \mathrm{C}) /(\Delta \mathrm{O}: \mathrm{C})$. As organics become more oxidized during gas-phase oxidation of VOC, the dominant reaction transitions from functionalization to fragmentation (Lambe et al., 2012; Zhao et al., 2015). Other studies also suggest that at a $\mathrm{O}: \mathrm{C}$ value of 0.4 , about $80 \%$ of gas-phase oxidation leads to fragmentation (Donahue et al., 2012; Jimenez et al., 2009). A fraction of the fragmented molecules, which have reduced molecular weight and higher $\mathrm{O}: \mathrm{C}$, can contribute to SOA by partitioning. We note autooxidation can also produce highly oxidized organics that contribute substantially to SOA (Ehn et al., 2014). For heterogeneous oxidation, fragmentation completely dominates once the organics reach a $\mathrm{O}: \mathrm{C}$ value of 0.4 , and the increase in $\mathrm{O}: \mathrm{C}$ ratio upon further oxidation is due to the loss of carbon rather than the addition of oxygen (Kroll et al., 2009). As an example, the fragmentation during heterogeneous oxidation of azelaic acid leads to lower molecular weight and a high $\kappa_{\text {org }}$ value, albeit for hygroscopic growth under subsaturated conditions (Cappa et al., 2011). In addition to functionalization and fragmentation discussed above, oligomerization also occurs during the formation and aging of the SOA. Laboratory-generated and ambient SOA particles may consist of a substantial number of oligomers that significantly impact SOA volatility (Kalberer et al., 2004). Several studies suggest that the formation of oligomers may occur on fast timescales, ranging from less than 1 to $\sim 30 \mathrm{~min}$ (e.g., Zaveri et al., 2018; Kolesar et al., 2015).

Further evidence for the fragmentation of organics during oxidation may derive from the hygroscopicity of highly oxidized SOA formed from precursors with a large molecular weight. For example, highly oxidized SOA formed from $n$ heptadecane $\left(\mathrm{C}_{17} \mathrm{H}_{36}\right)$ reaches a $\kappa_{\text {org }}$ value above 0.2 at an
$\mathrm{O}: \mathrm{C}$ value of 1.0 (Lambe et al., 2011). Based on the organic density estimated from the $\mathrm{O}: \mathrm{C}$ value of 1.0 and Eq. (2), a $\kappa_{\text {org }}$ value of 0.2 indicates a molecular weight between 130 and $160 \mathrm{~g} \mathrm{~mol}^{-1}$, corresponding to molecules with four to six carbon atoms. The above estimate assumes organics are completely dissolved (i.e., $\kappa_{\text {org }}=\kappa_{\text {org,intr }}$ ) and that nonideal solution effects are negligible at the point of activation. If the organics are only partially dissolved, the molecular weight would have to be even lower. As the precursor molecules have 17 carbon atoms, this indicates substantial fragmentation during the formation and oxidation of SOA, which leads to increased $\kappa_{\text {org }}$.

\subsection{A model for predicting the dependence of effective organic hygroscopicity on oxidation level}

Whereas the variation in precursor molecule size and fragmentation during oxidation described above explains the general trend in increasing $\kappa_{\text {org }}$ with the oxidation level, laboratory SOAs generated from a wide range of precursors with different vapor pressures, molecular weights, and structures exhibit nearly the same relationship between $\kappa_{\text {org }}$ and $\mathrm{O}: \mathrm{C}$ (Lambe et al., 2011). During the recent GoAmazon 2014/5 field campaign, $\kappa_{\text {org }}$ of various SOA components was derived and the variation in $\kappa_{\text {org }}$ with $\mathrm{O}: \mathrm{C}$ also follows a relationship similar to that observed in laboratory studies (Thalman et al., 2017). While such a "universal" relationship allows efficient parameterization of $\kappa_{\mathrm{org}}$ based on $\mathrm{O}: \mathrm{C}$, it also raises the question of why such a universal relationship is applicable to SOA generated from a range of precursors and under different conditions. As we show next, this universal relationship to a large degree derives from the interplay among molecular weight, oxidation level, and volatility in the absence of solubility limitation on droplet activation. In essence, to have sufficiently low volatility and contribute substantially to SOA, smaller organic molecules, which have higher $\kappa_{\text {org }}$ values due to their lower molecular weight based on Eq. (2), need to be more oxidized (i.e., higher $\mathrm{O}: \mathrm{C}$ ). Taking advantage of the finding that droplet activation of representative SOA is not limited by water solubility, we construct a simple model of the SOA hygroscopicity parameter based on molecular weight, oxidation level, and volatility. This simple model can reproduce the relationship between $\kappa_{\text {org }}$ and $\mathrm{O}: \mathrm{C}$ observed in the laboratory and field studies.

The volatility of aerosol organics can be estimated using a simple three-parameter group contribution expression (Donahue et al., 2011):

$\log _{10} C^{*}=-0.475 \times\left(n_{\mathrm{C}}-25\right)-1.7 \times n_{\mathrm{O}}$,

where $C^{*}\left(\mu \mathrm{g} \mathrm{m}^{3}\right)$ is the volatility at $293.15 \mathrm{~K}$, and $n_{\mathrm{C}}$ and $n_{\mathrm{O}}$ are the number of carbon and oxygen atoms of organic molecules, respectively. Equation (3) indicates that adding a carbon reduces the volatility by about half a decade, while adding an oxygen atom on average reduces the volatility by approximately 1.7 decades. From Eq. (3), we can derive $n_{\mathrm{O}}$ 

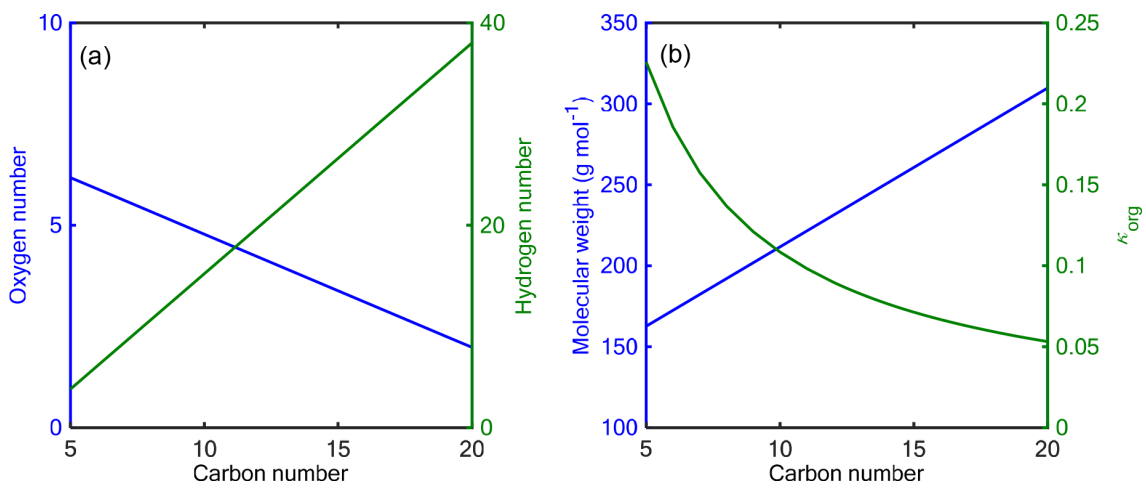

Figure 4. Oxygen and hydrogen numbers (a) and molecular weight and $\kappa_{\mathrm{org}}(\mathbf{b})$ as functions of carbon number for secondary organic species with a volatility $C^{*}$ of $0.1 \mu \mathrm{g} \mathrm{m}{ }^{-3}$ (i.e., $\log _{10} C^{*}=-1$ ).

as a function of $n_{\mathrm{C}}$ and $\log _{10} C^{*}$ :

$n_{\mathrm{O}}=-\frac{0.475}{1.7} \times\left(n_{\mathrm{C}}-25\right)-\frac{1}{1.7} \log _{10} C^{*}$

The hydrogen number can then be estimated using the approximation (Heald et al., 2010; Donahue et al., 2011)

$n_{\mathrm{H}} / n_{\mathrm{C}} \simeq 2-n_{\mathrm{O}} / n_{\mathrm{C}}$

Once $n_{\mathrm{C}}, n_{\mathrm{O}}$, and $n_{\mathrm{H}}$ are available, molecular weight and the organic density can be derived from $\mathrm{H}: \mathrm{C}$ and $\mathrm{O}: \mathrm{C}$ ratios (Kuwata et al., 2012). The approximation of Eq. (5) has a negligible impact on the molecular weight given the low atomic mass of hydrogen.

As the CCN activation of most SOA is not limited by its water solubility, $\kappa_{\text {org }}$ is the same as $\kappa_{\text {org,intr }}$, which can be derived from organic density and molecular weight using Eq. (2), assuming a van't Hoff factor of 1. Therefore, $\kappa_{\text {org }}$ and $\mathrm{O}: \mathrm{C}$ can be derived from $n_{\mathrm{C}}$ and $\log _{10} C^{*}$ by combining Eqs. (2)-(5). As an example, Fig. 4 shows $n_{\mathrm{O}}, n_{\mathrm{H}}$, molecular weight, and $\kappa_{\text {org }}$ as functions of carbon number for organic species with volatility $C^{*}$ of $0.1 \mu \mathrm{g} \mathrm{m}^{-3}$ (i.e., $\log _{10} C^{*}=-1$ ). For organic species with the same volatility, $n_{\mathrm{O}}$ decreases with increasing $n_{\mathrm{C}}$, indicating that for organics with the same volatility, those with a higher carbon number tend to be less oxidized. Despite a decreasing $n_{\mathrm{O}}$, molecular weight increases with increasing $n_{\mathrm{C}}$, leading to a lower hygroscopicity parameter via Eq. (2).

Obviously ambient organic aerosols exhibit a range of volatilities. Previous studies suggest that the mean $\log _{10} C^{*}$ of ambient organics largely falls within the range of -5 to -1 (e.g., Saha et al., 2017; Stark et al., 2017). The value of $\kappa_{\text {org }}$ derived from Eqs. (2)-(5) is plotted against $\mathrm{O}: \mathrm{C}$ for organics with a $\log _{10} C^{*}$ value ranging from -5 to -1 in Fig. 5. For organics with the same volatility, $\kappa_{\text {org }}$ increases nearly linearly with the $\mathrm{O}: \mathrm{C}$ ratio. Despite the difference in $C^{*}$ of 4 orders of magnitude, the derived variation in $\kappa_{\mathrm{org}}$ with $\mathrm{O}$ : $\mathrm{C}$ falls within a relatively narrow band. Figure 5 also shows the linear relationship between $\kappa_{\text {org }}$ with $\mathrm{O}: \mathrm{C}$ derived

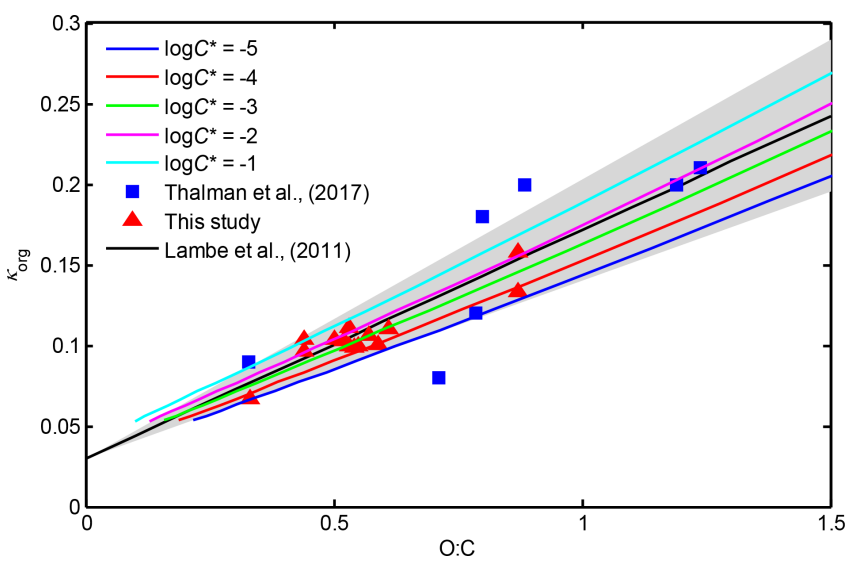

Figure 5. Predicted variation in $\kappa_{\mathrm{org}}$ as a function of $\mathrm{O}: \mathrm{C}$ for organics with a mean $\log _{10} C^{*}$ ranging from -1 to -5 . Also shown are $\kappa_{\text {org }}$ values of SOA positive matrix factorization (PMF) factors derived from measurements during GoAmazon 2014/5 (Thalman et al., 2017), $\kappa_{\text {org }}$ for SOA formed from isoprene, monoterpene, $\beta$ caryophyllene, and toluene in this study, and the relationship between $\kappa_{\text {org }}$ and $\mathrm{O}: \mathrm{C}$ for SOA derived from a laboratory study (Lambe et al., 2011). The shaded area represents the uncertainty in the derived relationship (Lambe et al., 2011).

by Lambe et al. (2011) for laboratory-generated SOA with a wide range of $\mathrm{O}: \mathrm{C}$ values, the SOA hygroscopicity parameter derived from this study, and the hygroscopicity parameter of SOA factors derived from the measurements during the recent GoAmazon 2014/5 campaign (Thalman et al., 2017). For $\beta$-caryophyllene SOA, $\kappa_{\text {org }}$ shown in Fig. 5 is the average value when $x_{\mathrm{AS}}$ is larger than $15 \%$ (i.e., when droplet activation is not limited by the solubility of $\beta$-caryophyllene SOA). The uncertainty range of the relationship derived by Lambe et al. (2011) is shown as the shaded area in Fig. 5. The $\kappa_{\text {org }}$ values derived from both the laboratory studies and field observation largely fall within the range of $\kappa_{\text {org }}$ derived from Eqs. (2)-(5) for $\mathrm{O}: \mathrm{C}$ from 0 to 1.5 , indicating the simple model successfully captures the major variation in $\kappa_{\text {org }}$ 
with $\mathrm{O}: \mathrm{C}$ for SOA at droplet activation (i.e., under supersaturated conditions).

The above derivation of the relationship assumes that molecules contain only hydroxyl and carbonyl groups (Donahue et al., 2011). While the volatility of molecules with other functional groups is less accurately represented, many typical functional groups in ambient aerosol organics are reasonably approximated as carbonyls, alcohols, or some combination of the two (Daumit et al., 2013). For example, an acid group decreases saturation vapor pressure by 3.58 decades, similar to 3.4 (i.e., $1.7 \times 2$ ) indicated by Eq. (3). While not all functional groups (e.g., acyclic ethers) are well represented by the above treatment (Daumit et al., 2013), we expect the general trend that $n_{\mathrm{O}}$ decreases with increasing $n_{\mathrm{C}}$ for organic compounds with the same volatility is robust. As the modeled relationship between $\kappa_{\text {org }}$ and $\mathrm{O}: \mathrm{C}$ falls within a relatively narrow area for organics with a mean $\log _{10} C^{*}$ ranging from -5 to -1 , the uncertainties associated with Eq. (3) are unlikely to substantially change the modeled relationships. Similar expressions of $\log _{10} C^{*}$ as a function of carbon and oxygen numbers were also proposed in earlier studies (Daumit et al., 2013; Pankow and Asher, 2008; Nakao, 2017; Li et al., 2016), and they do not lead to substantial differences in the results presented. The good agreement between the modeled relationships and those derived from laboratory and field measurements suggests that the increasing SOA hygroscopicity with $\mathrm{O}: \mathrm{C}$ to a large degree derives from the relationship among molecular weight, $\mathrm{O}: \mathrm{C}$, and volatility that controls gas-particle partitioning and formation of SOA.

While the results indicate that droplet activation and $\kappa_{\text {org }}$ are not limited by water solubility for most SOAs, we note primary organic aerosols are often hydrophobic, and droplet activation of these particles is expected to be strongly limited by the very low solubility of primary organic species. Lambe et al. (2011) showed that the relationship between $\kappa_{\text {org }}$ and $\mathrm{O}: \mathrm{C}$ for oxidized primary organic aerosol differs from that of SOA, suggesting that at the same $\mathrm{O}: \mathrm{C}$, oxidized primary organic aerosols have a lower $\kappa_{\text {org }}$ value than SOA due to the limitation of solubility.

\section{Conclusions}

Organic aerosols were generated by condensation of secondary organic species onto $50 \mathrm{~nm}$ ammonium sulfate seeds in a steady-state environmental chamber. For SOA generated from $\alpha$-pinene, $\Delta-3$ carene, isoprene, and toluene, the effective hygroscopicity parameter of organic species remains largely constant for particles with different sulfate volume fractions, suggesting that for most SOAs, the droplet activation is not limited by organic water solubility, and $\kappa_{\text {org }}$ at droplet activation is controlled mainly by the molecular weight of the organic species. We note there can be exceptions to this finding. Whereas on the global scale, SOA is dominated by SOAs formed from isoprene, monoterpene, and small aromatic hydrocarbons such as toluene, SOAs produced from large alkanes and aromatics are potentially important in the urban atmosphere (Gentner et al., 2017), and their droplet activation may be limited by organic water solubility, especially when the volume fraction of inorganics in the particles is low. The absence of limitation by water solubility indicates that the increase in organic hygroscopicity with the organic oxidation level cannot be attributed to higher water solubility of more oxidized organic compounds. Instead, the increase in the organic hygroscopicity with oxidation level is to a large degree due to the fact that (a) as a result of gas-particle partitioning, SOA formed from smaller parent VOC molecules tends to have lower molecular weight and is more oxidized and (b) during oxidation of SOA, fragmentation reactions produce organic molecules with lower molecular weight and therefore higher hygroscopicity. Taking advantage of the finding that droplet activation of SOA is not limited by water solubility, we developed a simple model of SOA hygroscopicity based on molecular weight, oxidation level, and volatility. This model is shown to reproduce the variation in $\kappa_{\text {org }}$ with $\mathrm{O}: \mathrm{C}$ observed from previous laboratory and field studies. These results provide a mechanistic understanding of the variation in organic hygroscopicity, which is expected to help improve the quantification of aerosol impact on clouds and climate.

Data availability. The data in the study are available upon reasonable request to Jian Wang (jian@wustl.edu).

Supplement. The supplement related to this article is available online at: https://doi.org/10.5194/acp-19-941-2019-supplement.

Author contributions. JW and JES designed the research. JW, JES, JL, AZ, DMB, RT, and GZ carried out the measurements. JW, JES, $\mathrm{AZ}$, and MDP led the analyses, and JW led the writing, with major input from MDP, JES, and AZ and further input from all other authors.

Competing interests. The authors declare that they have no conflict of interest.

Acknowledgements. This research was conducted with funding from the Atmospheric System Research (ASR) program (Office of Biological and Environmental Research of the U.S. Department of Energy) under contracts DE-AC02-98CH10886 and DE-AC0576RL01830. Markus D. Petters acknowledges additional support from the Office of Biological and Environmental Research of U.S. Department of Energy DE-SC 0012043. We acknowledge additional support by the Atmospheric Radiation Measurement (ARM) Climate Research Facility and Environmental Molecular 
Sciences Laboratory (EMSL), user facilities of the U.S. Department of Energy, Office of Science, sponsored by the Office of Biological and Environmental Research.

Edited by: Maria Cristina Facchini

Reviewed by: two anonymous referees

\section{References}

Albrecht, B. A.: Aerosols, cloud microphysics, and fractional cloudiness, Science, 245, 1227-1230, 1989.

Alfarra, M. R., Good, N., Wyche, K. P., Hamilton, J. F., Monks, P. S., Lewis, A. C., and McFiggans, G.: Water uptake is independent of the inferred composition of secondary aerosols derived from multiple biogenic VOCs, Atmos. Chem. Phys., 13, 1176911789, https://doi.org/10.5194/acp-13-11769-2013, 2013.

Asa-Awuku, A., Engelhart, G. J., Lee, B. H., Pandis, S. N., and Nenes, A.: Relating CCN activity, volatility, and droplet growth kinetics of $\beta$-caryophyllene secondary organic aerosol, Atmos. Chem. Phys., 9, 795-812, https://doi.org/10.5194/acp-9795-2009, 2009.

Bertram, A. K., Martin, S. T., Hanna, S. J., Smith, M. L., Bodsworth, A., Chen, Q., Kuwata, M., Liu, A., You, Y., and Zorn, S. R.: Predicting the relative humidities of liquid-liquid phase separation, efflorescence, and deliquescence of mixed particles of ammonium sulfate, organic material, and water using the organic-to-sulfate mass ratio of the particle and the oxygen-tocarbon elemental ratio of the organic component, Atmos. Chem. Phys., 11, 10995-11006, https://doi.org/10.5194/acp-11-109952011, 2011.

Bilde, M. and Svenningsson, B.: CCN activation of slightly soluble organics: the importance of small amounts of inorganic salt and particle phase, Tellus B, 56, 128-134, https://doi.org/10.1111/j.1600-0889.2004.00090.x, 2004.

Cappa, C. D., Che, D. L., Kessler, S. H., Kroll, J. H., and Wilson, K. R.: Variations in organic aerosol optical and hygroscopic properties upon heterogeneous OH oxidation, J. Geophys. Res., 116, D15204, https://doi.org/10.1029/2011jd015918, 2011.

Daumit, K. E., Kessler, S. H., and Kroll, J. H.: Average chemical properties and potential formation pathways of highly oxidized organic aerosol, Faraday Discuss., 165, 181-202, https://doi.org/10.1039/c3fd00045a, 2013.

Donahue, N. M., Epstein, S. A., Pandis, S. N., and Robinson, A. L.: A two-dimensional volatility basis set: 1. organic-aerosol mixing thermodynamics, Atmos. Chem. Phys., 11, 3303-3318, https://doi.org/10.5194/acp-11-3303-2011, 2011.

Donahue, N. M., Henry, K. M., Mentel, T. F., Kiendler-Scharr, A., Spindler, C., Bohn, B., Brauers, T., Dorn, H. P., Fuchs, H., Tillmann, R., Wahner, A., Saathoff, H., Naumann, K. H., Mohler, O., Leisner, T., Muller, L., Reinnig, M. C., Hoffmann, T., Salo, K., Hallquist, M., Frosch, M., Bilde, M., Tritscher, T., Barmet, P., Praplan, A. P., DeCarlo, P. F., Dommen, J., Prevot, A. S. H., and Baltensperger, U.: Aging of biogenic secondary organic aerosol via gas-phase $\mathrm{OH}$ radical reactions, P. Natl. Acad. Sci. USA, 109, 13503-13508, https://doi.org/10.1073/pnas.1115186109, 2012.

Ehn, M., Thornton, J. A., Kleist, E., Sipila, M., Junninen, H., Pullinen, I., Springer, M., Rubach, F., Tillmann, R., Lee, B., Lopez-Hilfiker, F., Andres, S., Acir, I. H., Rissanen, M., Joki- nen, T., Schobesberger, S., Kangasluoma, J., Kontkanen, J., Nieminen, T., Kurten, T., Nielsen, L. B., Jorgensen, S., Kjaergaard, H. G., Canagaratna, M., Dal Maso, M., Berndt, T., Petaja, T., Wahner, A., Kerminen, V. M., Kulmala, M., Worsnop, D. R., Wildt, J., and Mentel, T. F.: A large source of lowvolatility secondary organic aerosol, Nature, 506, 476-479, https://doi.org/10.1038/nature13032, 2014.

Ervens, B., Feingold, G., and Kreidenweis, S. M.: Influence of water-soluble organic carbon on cloud drop number concentration, J. Geophys. Res., 110, D18211, https://doi.org/10.1029/2004jd005634, 2005.

Forestieri, S. D., Staudt, S. M., Kuborn, T. M., Faber, K., Ruehl, C. R., Bertram, T. H., and Cappa, C. D.: Establishing the impact of model surfactants on cloud condensation nuclei activity of sea spray aerosol mimics, Atmos. Chem. Phys., 18, 10985-11005, https://doi.org/10.5194/acp-18-10985-2018, 2018.

Frosch, M., Bilde, M., Nenes, A., Praplan, A. P., Jurányi, Z., Dommen, J., Gysel, M., Weingartner, E., and Baltensperger, U.: $\mathrm{CCN}$ activity and volatility of $\beta$-caryophyllene secondary organic aerosol, Atmos. Chem. Phys., 13, 2283-2297, https://doi.org/10.5194/acp-13-2283-2013, 2013.

Gentner, D. R., Jathar, S. H., Gordon, T. D., Bahreini, R., Day, D. A., El Haddad, I., Hayes, P. L., Pieber, S. M., Platt, S. M., de Gouw, J., Goldstein, A. H., Harley, R. A., Jimenez, J. L., Prévôt, A. S. H., and Robinson, A. L.: Review of Urban Secondary Organic Aerosol Formation from Gasoline and Diesel Motor Vehicle Emissions, Environ. Sci. Technol., 51, 1074 1093, https://doi.org/10.1021/acs.est.6b04509, 2017.

Guenther, A. B., Jiang, X., Heald, C. L., Sakulyanontvittaya, T., Duhl, T., Emmons, L. K., and Wang, X.: The Model of Emissions of Gases and Aerosols from Nature version 2.1 (MEGAN2.1): an extended and updated framework for modeling biogenic emissions, Geosci. Model Dev., 5, 1471-1492, https://doi.org/10.5194/gmd-5-1471-2012, 2012.

Heald, C. L., Kroll, J. H., Jimenez, J. L., Docherty, K. S., DeCarlo, P. F., Aiken, A. C., Chen, Q., Martin, S. T., Farmer, D. K., and Artaxo, P.: A simplified description of the evolution of organic aerosol composition in the atmosphere, Geophys. Res. Lett., 37, L08803, https://doi.org/10.1029/2010g1042737, 2010

Hori, M., Ohta, S., Murao, N., and Yamagata, S.: Activation capability of water soluble organic substances as CCN, J. Aerosol Sci., 34, 419-448, 2003.

IPCC: Climate Change 2013: The Physical Science Basis: Contribution of Working Group I to the Fourth Assessment Report of the Intergovernmental Panel on Climate Change, edited by: Solomon, S. E. A., Cambridge University Press, New York, 2013. Jimenez, J. L., Canagaratna, M. R., Donahue, N. M., Prevot, A. S. H., Zhang, Q., Kroll, J. H., DeCarlo, P. F., Allan, J. D., Coe, H., Ng, N. L., Aiken, A. C., Docherty, K. S., Ulbrich, I. M., Grieshop, A. P., Robinson, A. L., Duplissy, J., Smith, J. D., Wilson, K. R., Lanz, V. A., Hueglin, C., Sun, Y. L., Tian, J., Laaksonen, A., Raatikainen, T., Rautiainen, J., Vaattovaara, P., Ehn, M., Kulmala, M., Tomlinson, J. M., Collins, D. R., Cubison, M J., Dunlea, E. J., Huffman, J. A., Onasch, T. B., Alfarra, M. R., Williams, P. I., Bower, K., Kondo, Y., Schneider, J., Drewnick, F., Borrmann, S., Weimer, S., Demerjian, K., Salcedo, D., Cottrell, L., Griffin, R., Takami, A., Miyoshi, T., Hatakeyama, S., Shimono, A., Sun, J. Y., Zhang, Y. M., Dzepina, K., Kimmel, J. R., Sueper, D., Jayne, J. T., Herndon, S. C., Trimborn, A. M., 
Williams, L. R., Wood, E. C., Middlebrook, A. M., Kolb, C. E., Baltensperger, U., and Worsnop, D. R.: Evolution of Organic Aerosols in the Atmosphere, Science, 326, 1525-1529, 2009.

Kalberer, M., Paulsen, D., Sax, M., Steinbacher, M., Dommen, J., Prevot, A. S. H., Fisseha, R., Weingartner, E., Frankevich, V., Zenobi, R., and Baltensperger, U.: Identification of polymers as major components of atmospheric organic aerosols, Science, 303, 1659-1662, https://doi.org/10.1126/science.1092185, 2004.

King, S. M., Rosenoern, T., Shilling, J. E., Chen, Q., Wang, Z., Biskos, G., McKinney, K. A., Pöschl, U., and Martin, S. T.: Cloud droplet activation of mixed organic-sulfate particles produced by the photooxidation of isoprene, Atmos. Chem. Phys., 10, 3953-3964, https://doi.org/10.5194/acp-103953-2010, 2010.

Kolesar, K. R., Li, Z. Y., Wilson, K. R., and Cappa, C. D.: Heating-Induced Evaporation of Nine Different Secondary Organic Aerosol Types, Environ. Sci. Technol., 49, 12242-12252, https://doi.org/10.1021/acs.est.5b03038, 2015.

Kroll, J. H., Smith, J. D., Che, D. L., Kessler, S. H., Worsnop, D. R., and Wilson, K. R.: Measurement of fragmentation and functionalization pathways in the heterogeneous oxidation of oxidized organic aerosol, Phys. Chem. Chem. Phys., 11, 8005-8014, https://doi.org/10.1039/b905289e, 2009.

Kuwata, M., Zorn, S. R., and Martin, S. T.: Using Elemental Ratios to Predict the Density of Organic Material Composed of Carbon, Hydrogen, and Oxygen, Environ. Sci. Technol., 46, 787794, 2012.

Kuwata, M., Shao, W., Lebouteiller, R., and Martin, S. T.: Classifying organic materials by oxygen-to-carbon elemental ratio to predict the activation regime of Cloud Condensation Nuclei (CCN), Atmos. Chem. Phys., 13, 5309-5324, https://doi.org/10.5194/acp-13-5309-2013, 2013.

Lambe, A. T., Onasch, T. B., Massoli, P., Croasdale, D. R., Wright, J. P., Ahern, A. T., Williams, L. R., Worsnop, D. R., Brune, W. H., and Davidovits, P.: Laboratory studies of the chemical composition and cloud condensation nuclei $(\mathrm{CCN})$ activity of secondary organic aerosol (SOA) and oxidized primary organic aerosol (OPOA), Atmos. Chem. Phys., 11, 8913-8928, https://doi.org/10.5194/acp-11-8913-2011, 2011.

Lambe, A. T., Onasch, T. B., Croasdale, D. R., Wright, J. P., Martin, A. T., Franklin, J. P., Massoli, P., Kroll, J. H., Canagaratna, M. R., Brune, W. H., Worsnop, D. R., and Davidovits, P.: Transitions from Functionalization to Fragmentation Reactions of Laboratory Secondary Organic Aerosol (SOA) Generated from the OH Oxidation of Alkane Precursors, Environ. Sci. Technol., 46, 5430-5437, https://doi.org/10.1021/es300274t, 2012.

Lathem, T. L., Beyersdorf, A. J., Thornhill, K. L., Winstead, E. L., Cubison, M. J., Hecobian, A., Jimenez, J. L., Weber, R. J., Anderson, B. E., and Nenes, A.: Analysis of CCN activity of Arctic aerosol and Canadian biomass burning during summer 2008, Atmos. Chem. Phys., 13, 2735-2756, https://doi.org/10.5194/acp13-2735-2013, 2013.

Li, Y., Pöschl, U., and Shiraiwa, M.: Molecular corridors and parameterizations of volatility in the chemical evolution of organic aerosols, Atmos. Chem. Phys., 16, 3327-3344, https://doi.org/10.5194/acp-16-3327-2016, 2016.

Liu, X. H. and Wang, J. A.: How important is organic aerosol hygroscopicity to aerosol indirect forcing?, Environ. Res. Lett., 5, 044010, https://doi.org/10.1088/1748-9326/5/4/044010, 2010.
Marcolli, C., Luo, B. P., and Peter, T.: Mixing of the organic aerosol fractions: Liquids as the thermodynamically stable phases, J. Phys. Chem. A, 108, 2216-2224, https://doi.org/10.1021/jp0360801, 2004.

McFiggans, G., Artaxo, P., Baltensperger, U., Coe, H., Facchini, M. C., Feingold, G., Fuzzi, S., Gysel, M., Laaksonen, A., Lohmann, U., Mentel, T. F., Murphy, D. M., O’Dowd, C. D., Snider, J. R., and Weingartner, E.: The effect of physical and chemical aerosol properties on warm cloud droplet activation, Atmos. Chem. Phys., 6, 2593-2649, https://doi.org/10.5194/acp-6-25932006, 2006.

Mei, F., Setyan, A., Zhang, Q., and Wang, J.: CCN activity of organic aerosols observed downwind of urban emissions during CARES, Atmos. Chem. Phys., 13, 12155-12169, https://doi.org/10.5194/acp-13-12155-2013, 2013.

Mikhailov, E., Vlasenko, S., Martin, S. T., Koop, T., and Pöschl, U.: Amorphous and crystalline aerosol particles interacting with water vapor: conceptual framework and experimental evidence for restructuring, phase transitions and kinetic limitations, Atmos. Chem. Phys., 9, 9491-9522, https://doi.org/10.5194/acp-9-94912009, 2009.

Moore, R. H., Cerully, K., Bahreini, R., Brock, C. A., Middlebrook, A. M., and Nenes, A.: Hygroscopicity and composition of California CCN during summer 2010, J. Geophys. Res., 117, D00V12, https://doi.org/10.1029/2011JD017352, 2012.

Nakao, S.: Why would apparent kappa linearly change with O/C? Assessing the role of volatility, solubility, and surface activity of organic aerosols, Aerosol Sci. Technol., 51, 1377-1388, https://doi.org/10.1080/02786826.2017.1352082, 2017.

Ng, N. L., Canagaratna, M. R., Jimenez, J. L., Chhabra, P. S., Seinfeld, J. H., and Worsnop, D. R.: Changes in organic aerosol composition with aging inferred from aerosol mass spectra, Atmos. Chem. Phys., 11, 6465-6474, https://doi.org/10.5194/acp11-6465-2011, 2011.

Noziere, B., Baduel, C., and Jaffrezo, J. L.: The dynamic surface tension of atmospheric aerosol surfactants reveals new aspects of cloud activation, Nat. Commun., 5, 3335, https://doi.org/10.1038/ncomms4335, 2014.

Ovadnevaite, J., Zuend, A., Laaksonen, A., Sanchez, K. J., Roberts, G., Ceburnis, D., Decesari, S., Rinaldi, M., Hodas, N., Facchini, M. C., Seinfeld, J. H., and Dowd, C. O.: Surface tension prevails over solute effect in organic-influenced cloud droplet activation, Nature, 546, 637-641, https://doi.org/10.1038/nature22806, 2017.

Pankow, J. F. and Asher, W. E.: SIMPOL.1: a simple group contribution method for predicting vapor pressures and enthalpies of vaporization of multifunctional organic compounds, Atmos. Chem. Phys., 8, 2773-2796, https://doi.org/10.5194/acp-8-27732008, 2008.

Petters, M. D. and Kreidenweis, S. M.: A single parameter representation of hygroscopic growth and cloud condensation nucleus activity, Atmos. Chem. Phys., 7, 1961-1971, https://doi.org/10.5194/acp-7-1961-2007, 2007.

Petters, M. D. and Kreidenweis, S. M.: A single parameter representation of hygroscopic growth and cloud condensation nucleus activity - Part 2: Including solubility, Atmos. Chem. Phys., 8, 6273-6279, https://doi.org/10.5194/acp-8-6273-2008, 2008.

Petters, M. D., Kreidenweis, S. M., Snider, J. R., Koehler, K. A., Wang, Q., Prenni, A. J., and Demott, P. J.: Cloud droplet acti- 
vation of polymerized organic aerosol, Tellus B, 58, 196-205, https://doi.org/10.1111/j.1600-0889.2006.00181.x, 2006.

Petters, M. D., Kreidenweis, S. M., Prenni, A. J., Sullivan, R. C., Carrico, C. M., Koehler, K. A., and Ziemann, P. J.: Role of molecular size in cloud droplet activation, Geophys. Res. Lett., 36, L22801, https://doi.org/10.1029/2009GL040131, 2009.

Petters, M. D., Kreidenweis, S. M., and Ziemann, P. J.: Prediction of cloud condensation nuclei activity for organic compounds using functional group contribution methods, Geosci. Model Dev., 9, 111-124, https://doi.org/10.5194/gmd-9-111-2016, 2016.

Petters, S. S. and Petters, M. D.: Surfactant effect on cloud condensation nuclei for two-component internally mixed aerosols, J. Geophys. Res., 121, 1878-1895, https://doi.org/10.1002/2015jd024090, 2016.

Pringle, K. J., Tost, H., Pozzer, A., Pöschl, U., and Lelieveld, J.: Global distribution of the effective aerosol hygroscopicity parameter for CCN activation, Atmos. Chem. Phys., 10, 52415255, https://doi.org/10.5194/acp-10-5241-2010, 2010.

Prisle, N. L., Raatikainen, T., Laaksonen, A., and Bilde, M.: Surfactants in cloud droplet activation: mixed organicinorganic particles, Atmos. Chem. Phys., 10, 5663-5683, https://doi.org/10.5194/acp-10-5663-2010, 2010.

Pye, H. O. T., Chan, A. W. H., Barkley, M. P., and Seinfeld, J. H.: Global modeling of organic aerosol: the importance of reactive nitrogen $\left(\mathrm{NO}_{\mathrm{x}}\right.$ and $\left.\mathrm{NO}_{3}\right)$, Atmos. Chem. Phys., 10, 1126111276, https://doi.org/10.5194/acp-10-11261-2010, 2010.

Rickards, A. M. J., Miles, R. E. H., Davies, J. F., Marshall, F. H., and Reid, J. P.: Measurements of the Sensitivity of Aerosol Hygroscopicity and the kappa Parameter to the O/C Ratio, J. Phys. Chem. A, 117, 14120-14131, https://doi.org/10.1021/jp407991n, 2013.

Riipinen, I., Rastak, N., and Pandis, S. N.: Connecting the solubility and $\mathrm{CCN}$ activation of complex organic aerosols: a theoretical study using solubility distributions, Atmos. Chem. Phys., 15, 6305-6322, https://doi.org/10.5194/acp-15-6305-2015, 2015.

Rothfuss, N. E. and Petters, M. D.: Influence of Functional Groups on the Viscosity of Organic Aerosol, Environ. Sci. Technol., 51, 271-279, https://doi.org/10.1021/acs.est.6b04478, 2017.

Ruehl, C. R., Davies, J. F., and Wilson, K. R.: An interfacial mechanism for cloud droplet formation on organic aerosols, Science, 351, 1447-1450, https://doi.org/10.1126/science.aad4889, 2016.

Saha, P. K., Khlystov, A., Yahya, K., Zhang, Y., Xu, L., Ng, N. L., and Grieshop, A. P.: Quantifying the volatility of organic aerosol in the southeastern US, Atmos. Chem. Phys., 17, 501520, https://doi.org/10.5194/acp-17-501-2017, 2017.

Shilling, J. E., Chen, Q., King, S. M., Rosenoern, T., Kroll, J. H., Worsnop, D. R., McKinney, K. A., and Martin, S. T.: Particle mass yield in secondary organic aerosol formed by the dark ozonolysis of a-pinene, Atmos. Chem. Phys., 8, 2073-2088, https://doi.org/10.5194/acp-8-2073-2008, 2008.

Shiraiwa, M., Li, Y., Tsimpidi, A. P., Karydis, V. A., Berkemeier, T., Pandis, S. N., Lelieveld, J., Koop, T., and Pöoschl, U.: Global distribution of particle phase state in atmospheric secondary organic aerosols, Nat. Commun., 8, 15002, https://doi.org/10.1038/ncomms15002, 2017.

Shulman, M. L., Jacobson, M. C., Carlson, R. J., Synovec, R. E., and Young, T. E.: Dissolution behavior and surface tension effects of organic compounds in nucleating cloud droplets, Geophys. Res. Lett., 23, 277-280, 1996.
Sorjamaa, R., Svenningsson, B., Raatikainen, T., Henning, S., Bilde, M., and Laaksonen, A.: The role of surfactants in Köhler theory reconsidered, Atmos. Chem. Phys., 4, 2107-2117, https://doi.org/10.5194/acp-4-2107-2004, 2004.

Stark, H., Yatavelli, R. L. N., Thompson, S. L., Kang, H., Krechmer, J. E., Kimmel, J. R., Palm, B. B., Hu, W. W., Hayes, P. L., Day, D. A., Campuzano-Jost, P., Canagaratna, M. R., Jayne, J. T., Worsnop, D. R., and Jimenez, J. L.: Impact of Thermal Decomposition on Thermal Desorption Instruments: Advantage of Thermogram Analysis for Quantifying Volatility Distributions of Organic Species, Environ. Sci. Technol., 51, 8491-8500, https://doi.org/10.1021/acs.est.7b00160, 2017.

Sullivan, R. C., Moore, M. J. K., Petters, M. D., Kreidenweis, S. M., Roberts, G. C., and Prather, K. A.: Effect of chemical mixing state on the hygroscopicity and cloud nucleation properties of calcium mineral dust particles, Atmos. Chem. Phys., 9, 33033316, https://doi.org/10.5194/acp-9-3303-2009, 2009.

Thalman, R., de Sá, S. S., Palm, B. B., Barbosa, H. M. J., Pöhlker, M. L., Alexander, M. L., Brito, J., Carbone, S., Castillo, P., Day, D. A., Kuang, C., Manzi, A., Ng, N. L., Sedlacek III, A. J., Souza, R., Springston, S., Watson, T., Pöhlker, C., Pöschl, U., Andreae, M. O., Artaxo, P., Jimenez, J. L., Martin, S. T., and Wang, J.: CCN activity and organic hygroscopicity of aerosols downwind of an urban region in central Amazonia: seasonal and diel variations and impact of anthropogenic emissions, Atmos. Chem. Phys., 17, 11779-11801, https://doi.org/10.5194/acp-1711779-2017, 2017.

Topping, D.: An analytical solution to calculate bulk mole fractions for any number of components in aerosol droplets after considering partitioning to a surface layer, Geosci. Model Dev., 3, 635642, https://doi.org/10.5194/gmd-3-635-2010, 2010.

Twomey, S.: Influence of pollution on shortwave albedo of clouds, J. Atmos. Sci., 34, 1149-1152, 1977.

Varutbangkul, V., Brechtel, F. J., Bahreini, R., Ng, N. L., Keywood, M. D., Kroll, J. H., Flagan, R. C., Seinfeld, J. H., Lee, A., and Goldstein, A. H.: Hygroscopicity of secondary organic aerosols formed by oxidation of cycloalkenes, monoterpenes, sesquiterpenes, and related compounds, Atmos. Chem. Phys., 6, 23672388, https://doi.org/10.5194/acp-6-2367-2006, 2006.

Zaveri, R. A., Shilling, J. E., Zelenyuk, A., Liu, J. M., Bell, D. M., D’Ambro, E. L., Gaston, C., Thornton, J. A., Laskin, A., Lin, P., Wilson, J., Easter, R. C., Wang, J., Bertram, A. K., Martin, S. T., Seinfeld, J. H., and Worsnop, D. R.: Growth Kinetics and Size Distribution Dynamics of Viscous Secondary Organic Aerosol, Environ. Sci. Technol., 52, 1191-1199, https://doi.org/10.1021/acs.est.7b04623, 2018.

Zelenyuk, A., Yang, J., Song, C., Zaveri, R. A., and Imre, D.: A New Real-Time Method for Determining Particles' Sphericity and Density: Application to Secondary Organic Aerosol Formed by Ozonolysis of alpha-Pinene, Environ. Sci. Technol., 42, 80338038, https://doi.org/10.1021/es8013562, 2008.

Zhang, Q., Jimenez, J. L., Canagaratna, M. R., Allan, J. D., Coe, H., Ulbrich, I., Alfarra, M. R., Takami, A., Middlebrook, A. M., Sun, Y. L., Dzepina, K., Dunlea, E., Docherty, K., DeCarlo, P. F., Salcedo, D., Onasch, T., Jayne, J. T., Miyoshi, T., Shimono, A., Hatakeyama, S., Takegawa, N., Kondo, Y., Schneider, J., Drewnick, F., Borrmann, S., Weimer, S., Demerjian, K., Williams, P., Bower, K., Bahreini, R., Cottrell, L., Griffin, R. J., Rautiainen, J., Sun, J. Y., Zhang, Y. M., and 
Worsnop, D. R.: Ubiquity and dominance of oxygenated species in organic aerosols in anthropogenically-influenced Northern Hemisphere midlatitudes, Geophys. Res. Lett., 34, L13801, https://doi.org/10.1029/2007GL029979, 2007.

Zhao, D. F., Kaminski, M., Schlag, P., Fuchs, H., Acir, I.-H., Bohn, B., Häseler, R., Kiendler-Scharr, A., Rohrer, F., Tillmann, R., Wang, M. J., Wegener, R., Wildt, J., Wahner, A., and Mentel, Th. F.: Secondary organic aerosol formation from hydroxyl radical oxidation and ozonolysis of monoterpenes, Atmos. Chem. Phys., 15, 991-1012, https://doi.org/10.5194/acp-15-991-2015, 2015.
Zhao, D. F., Buchholz, A., Kortner, B., Schlag, P., Rubach, F., Fuchs, H., Kiendler-Scharr, A., Tillmann, R., Wahner, A., Watne, Å. K., Hallquist, M., Flores, J. M., Rudich, Y., Kristensen, K., Hansen, A. M. K., Glasius, M., Kourtchev, I., Kalberer, M., and Mentel, Th. F.: Cloud condensation nuclei activity, droplet growth kinetics, and hygroscopicity of biogenic and anthropogenic secondary organic aerosol (SOA), Atmos. Chem. Phys., 16, 1105-1121, https://doi.org/10.5194/acp16-1105-2016, 2016.

Zuend, A. and Seinfeld, J. H.: Modeling the gas-particle partitioning of secondary organic aerosol: the importance of liquidliquid phase separation, Atmos. Chem. Phys., 12, 3857-3882, https://doi.org/10.5194/acp-12-3857-2012, 2012. 